\title{
Penyitaan Barang Bukti Tindak Pidana pada Tingkat Pemeriksaan Persidangan
}

\author{
*Muhammad Ibnu Fajar Rahim1, Sitti Arkanul Pascahyati Rahim², \\ Muhammad Aman Hijrah Akbar Rahim33, Ahmad Ranuwirawan Rahim4, \\ Abdul Rahim ${ }^{5}$ \\ ${ }^{1}$ Kejaksaan Republik Indonesia \\ 2 Magister Ilmu Hukum, Universitas Muslim Indonesia \\ ${ }^{3}$ Fakultas Hukum, Universitas Hasanuddin \\ ${ }^{4}$ Badan Pusat Statistik, Buton Utara \\ ${ }^{5}$ Fakultas PPKn, Universitas Muhammadiyah Makassar \\ Email Correspondensi: muh.ibnu.fajar.rahim@kejaksaan.go.id \\ No. Handphone Correspondensi : +6281242602626
}

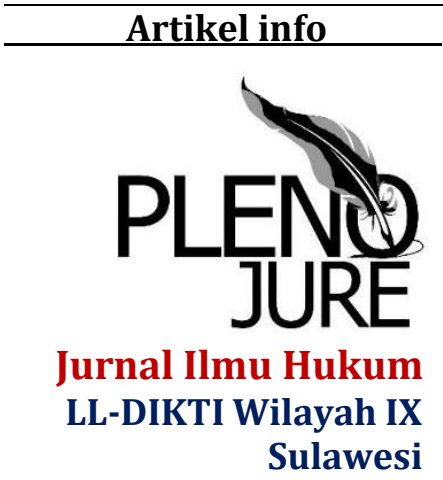

Artikel history:

Received : 20 April 2020

Revised : 27 April 2020

Accepted : 28 April 2020

\begin{abstract}
Abstrak. Penyitaan terhadap barang bukti sebagai coraborating evidence merupakan upaya paksa untuk memperkuat pembuktian dakwaan penuntut umum di persidangan. Realitasnya, masih terdapat barang bukti yang relevan dengan pembuktian dakwaan namun baru terungkap di persidangan dan belum dilakukan penyitaan. Ketentuan Pasal 38 ayat (1) KUHAP yang menegaskan penyitaan hanya dilakukan pada tingkat penyidikan oleh penyidik yang menjadikan penuntut umum kesulitan ketika berhadapan dengan realitas tersebut. Artikel ini berupaya menegaskan adanya kewenangan penuntut umum untuk melakukan penyitaan barang bukti tindak pidana pada tingkat pemeriksaan persidangan. Legal argumentasi penyitaan oleh penuntut umum ditemukan dalam PERJA 36/2011 maupun KMA 32/2006 sebagai bagian dari peraturan perundanganundangan.
\end{abstract}

Abstract. Confiscation of evidence as coraborating evidence is a forced effort to strengthen the evidence of the public prosecutor's charges at the trial. In reality, there is still evidence that is relevant to the indictment, but it has only been revealed at court and has not been confiscated. The provisions of Article 38 paragraph (1) of the Criminal Procedure Code which confirms confiscation are only carried out at the level of investigation by investigators which makes the public prosecutor difficult when dealing with this reality. This article seeks to emphasize the authority of the public prosecutor to confiscate evidence of a criminal offense at the trial examination level. Legal arguments for confiscation by the public prosecutor are found in PERJA 36/2011 and KMA 32/2006 as part of the legislation. 
Pleno Jure, Vol. 9 (1), Muh. Ibnu Fajar Rahim, et al, Penyitaan Barang Bukti ...

\section{Keywords:}

Penyitaan; Barang Bukti;

Persidangan; artikel dengan akses terbuka dibawah lisensi CC BY-SA 4.0

\section{PENDAHULUAN}

Inti dari Hukum Acara Pidana adalah pembuktian terjadinya pelanggaran terhadap hukum pidana materiil. Dari pembuktianlah diketahui seseorang terdakwa akan dinyatakan bersalah atau dibebaskan. UndangUndang Republik Indonesia Nomor 8 Tahun 1981 Tentang Hukum Acara Pidana (selanjutnya disebut KUHAP) yang lahir pada tanggal 31 Desember 1981 di Jakarta merupakan master piece atau karya agung bangsa Indonesia, telah mengatur penguraian cara bagaimana menyampaikan alat-alat bukti kepada hakim di pengadilan baik itu dari tahap penyelidikan, penyidikan, penuntutan, pemeriksaan persidangan, serta upaya hukum, dengan mengedapankan perlindungan terhadap hak asasi manusia sebagai bagian dari due process of law. Senada dengan postulat nullum crimen sine poena legali yang secara positif bermakna semua perbuatan pidana harus dipidana menurut undang-undang ${ }^{1}$, maka KUHAP sebagai the rule dalam beracara, menganut secara ketat 3 (tiga) prinsip legalitas, yakni lex certa yang bermakna tertulis, lex scripta yang bermakna jelas, serta lex stricta yang bermakna tidak boleh ditafsirkan lain selain apa yang tertulis dengan jelas. ${ }^{2}$ Konsekuensi logis dari prinsip legalitas tersebut, maka dalam mencari kebenaran materiil, penegak hukum baik itu penyidik, penuntut umum, hakim, penasihat hukum harus menggunakan cara-cara yang diatur dalam ketentuan KUHAP. Menyimpang dari KUHAP sebagai due process of law, maka hal tersebut merupakan exclusinary of rule, unlawfull legal evidence, maupun illegally acquired evidence, yang berujung pada dibebaskannya terdakwa. ${ }^{3}$

Untuk kepentingan pembuktian, kehadiran physical evidence atau real evidence atau yang dikenal sebagai barang bukti, sangat diperlukan untuk menjelaskan fakta kejadian tindak pidana. Untuk memperoleh barang bukti, dapat dilakukan melalui upaya paksa, yakni penyitaan. Penyitaan sangat mutlak di dalam proses penyidikan. Penyitaan bertujuan untuk menunjuk barang bukti sebagai hal utama dalam kepentingan pembuktian di muka persidangan, sebab barang bukti bersifat mutlak untuk dapat atau tidaknya, perkara diajukan ke pengadilan. ${ }^{4}$ Secara tegas, penyitaan adalah tindakan hukum yang dilakukan pada tingkat penyidik atau bagian dari kegiatan penyidikan. Dalam Pasal 38 ayat (1) KUHAP menyatakan bahwa penyitaan hanya dapat dilakukan oleh penyidik. Dengan penegasan pasal tersebut, maka telah ditentukan dengan pasti, hanya penyidik yang berwenang melakukan penyitaan.

Realitasnya, penuntut umum selaku pihak yang dikenai kewajiban untuk membuktikan tindak pidana (actori incumbit onus probandi) ${ }^{5}$ pada saat

\footnotetext{
${ }^{1}$ Eddy OS. Hiariej, (2009). Asas Legalitas dan Penemuan Hukum dalam Hukum Pidana, Erlangga, Jakarta, hlm. 27-28.

2 Pribadi, I. (2018). Legalitas Alat Bukti Elektronik Dalam Sistem Peradilan Pidana. Lex Renaissance, 3(1), 4.

${ }^{3}$ Eddy OS. Hiariej, (2012). Teori Dan Hukum Pembuktian, Erlangga, Jakarta, hlm. 20-22.

${ }^{4}$ Andi Sofyan dan Asis, (2014). Hukum Acara Pidana Suatu Pengantar, Prenadamedia Group, Jakarta, hal. 155.

${ }^{5}$ Satria, H. (2017). Ke Arah Pergeseran Beban Pembuktian. Integritas: Jurnal Antikorupsi Komisi Pemberantasan Korupsi, 3(1). hal, 90
} 
pemeriksaan persidangan menemukan fakta adanya barang bukti yang memiliki relevansi untuk membuktikan kesalahan terdakwa. Namun, barang bukti tersebut belum disita oleh penyidikan sehingga tidak menjadi barang bukti yang dapat memperkuat alat bukti dalam pembuktian. Oleh karena Pasal 38 ayat (1) KUHAP sebagai the rule dalam beracara secara tegas menyatakan kewenangan penyitaan hanya ada pada penyidik dan bukan pada penuntut umum, ${ }^{6,7}$ maka bagaimanakah tindakan yang dilakukan oleh penuntut umum dalam menghadapi realitas tersebut. Apakah prosedur hukum yang kaku dibarengi mindshet legal positivistik tersebut menghentikan langkah penuntut umum untuk membuktikan kebenaran materiil terhadap kesalahan terdakwa. Bagaimakah langkah penuntut umum untuk membebaskan diri dari the rule tersebut. Berdasarkan hal tersebut, maka penulis tertarik untuk menarasikan bagaimana konsep penyitaan pada tingkat penuntutan tindak pidana umum sebagai jawaban atas realitas tersebut.

\section{METODE}

Tulisan ini merupakan penelitian hukum normatif dengan pendekatan perundang-undangan, pendekatan kasus, dan pendekatan konseptual terhadap bahan hukum yang dikumpulkan melalui studi kepustakaan kemudian dianalisis menggunakan metode penafsiran gramatikal, sistematis, serta ekstensif.

\section{HASIL DAN PEMBAHASAN}

\section{Penyitaan Barang Bukti Dalam KUHAP}

Pengertian penyitaan dirumuskan dalam Pasal 1 butir ke-16 KUHAP yang berbunyi "Penyitaan adalah serangkaian tindakan penyidik untuk mengambil alih dan atau menyimpan di bawah penguasaannya benda bergerak atau tidak bergerak, berwujud atau tidak berwujud, untuk kepentingan pembuktian dalam penyidikan, penuntutan, dan peradilan". Dari defenisi penyitaan yang dimkasud oleh KUHAP tersebut, setidaknya diketahui beberapa hal terkait penyitaan, yakni 1) penyitaan adalah tindakan penyidik; 2) penyitaan dilakukan dengan mengambil alih dan atau menyimpan di bawah penguasaannya benda bergerak atau tidak bergerak, berwujud atau tidak berwujud; 3) objek yang dapat dilakukan penyitaan adalah benda bergerak atau tidak bergerak, berwujud atau tidak berwujud; 4) penyitaan dilakukan untuk kepentingan pembuktian dalam penyidikan, penuntutan, dan peradilan.

Pertama, penyitaan adalah tindakan penyidik. Sebagaimana disebutkan dalam Pasal 1 butir ke-1 KUHAP mendefinsikan penyidik adalah pejabat polisi negara Republik Indonesia atau pejabat pegawai negeri sipil tertentu yang diberi wewenang khusus oleh undang-undang untuk melakukan penyidikan. Hal yang menarik dalam KUHAP terkait profesi penyidik ini adalah profesi penyidik ditempatkan sebagai norma pertama dalam KUHAP. Entah apakah semangat dari pembentukan KUHAP adalah penguatan peran penyidik, namun fungsi penyidikan dalam sistem peradilan pidana mempunyai peranan yang sangat penting. Penyidikan yang dilakukan oleh penyidik merupakan gerbang awal dimulainya peradilan pidana. Lebih lanjut, dalam Pasal 7 ayat (1) huruf $d$

\footnotetext{
${ }^{6}$ Sumaidi, S. (2017). Kajian Terhadap Penyitaan Sebagai Pemaksaan Yang Dihalalkan Oleh Hukum. Legalitas: Jurnal Hukum, 8(1), 220-244.

${ }^{7}$ Panauhe, N. (2014). Akibat Hukum Peralihan Tanggung Jawab Penyidik Atas Benda Sitaan. Lex Crimen, 3(1). hal, 61
} 
KUHAP menyebutkan penyidik karena kewajibannya mempunyai wewenang melakukan penyitaan. Ditegaskan dalam Pasal 38 ayat (1) bahwa penyitaan hanya dapat dilakukan oleh penyidik dengan surat izin ketua pengadilan negeri setempat. Dari serangkain norma tersebut, maka penyitaan dalam perspektif KUHAP hanya dapat dilakukan oleh penyidik.

Kedua, penyitaan dilakukan dengan mengambil alih dan atau menyimpan di bawah penguasaannya benda bergerak atau tidak bergerak, berwujud atau tidak berwujud. Tindakan penyitaan merupakan tindak pro justisia yang dilakukan berdasarkan surat perintah maupun penetapan pengadilan. Tindakan mengambil alih dan atau menyimpan di bawah penguasaannya terhadap barang bukti merupakan serangkan upaya perampasan terhadap hak milik seseorang. Dalam Universal Declaration of Human Rights, hak milik orang dilindungi. Hal itu tercantum dalam Pasal 17 ayat (1) dan (2) yang berbunyi "(1) Everyone has the right to own property alone as well as in association with others, (2) No one shall be arbitrarily deprived of his property". Artinya, setiap orang berhak mempunyai milik baik sendiri maupun bersama-sama dengan orang lain dan tiada seorang pun boleh merampas miliknya dengan semena-mena. Penyitaan yang dilakukan guna kepentingan acara pidana dapat dilakukan dengan cara-cara yang telah ditentukan oleh undang-undang. ${ }^{8}$ Penyitaan dalam pengertian hukum acara pidana yang digariskan KUHAP adalah upaya paksa (dwang-middelen) yang dapat melanggar hak asasi manusia, yang dilakukan penyidik untuk a) mengambil atau merampas sesuatu barang tertentu dari seorang tersangka, pemegang atau penyimpan, tapi perampasan yang dilakukan dibenarkan hukum dan dilaksanakan menurut aturan undang-undang dan bukan perampasan liar dengan cara yang melawan hukum (wederechtelyk), serta b) setelah barangnya diambil atau dirampas oleh penyidik, ditaruh atau disimpan dibawah kekuasaannya. ${ }^{9}$ Tujuan penyitaan adalah untuk kepentingan pembuktian, terutama ditujukan sebagai barang bukti di muka sidang peradilan. Kemungkinan besar tanpa barang bukti, perkara tidak dapat diajukan ke sidang pengadilan. Oleh karena itu, agar perkara dinyatakan lengkap dengan barang bukti, penyidik melakukan penyitaan untuk dipergunakan sebagai bukti dalam penyidikan, dalam penuntutan dan pemeriksaan persidangan pengadilan. ${ }^{10}$

Ketiga, objek yang dapat dilakukan penyitaan adalah benda bergerak atau tidak bergerak, berwujud atau tidak berwujud. Dalam Pasal 39 KUHAP menyebutkan secara tegas barang-barang yang dapat dikenakan penyitaan adalah (a) benda atau tagihan tersangka atau terdakwa yang seluruhnya atau sebagian diduga diperoleh dari tindak pidana atau sebagai hasil dari tindak pidana; (b) benda yang telah dipergunakan secara langsung untuk melakukan tindak pidana atau untuk mempersiapkannya; (c) benda yang dipergunakan untuk menghalang-halangi penyidikan tindak pidana; (d) benda yang khusus dibuat atau diperuntukkan melakukan tindak pidana; (e) benda lain yang mempunyai hubungan langsung dengan tindak pidana yang dilakukan. Terkadang barang yang disita bukan milik tersangka. Adakalanya barang orang lain yang dikuasainya secara melawan hukum, seperti dalam perkara pidana pencurian, atau memang barang tersangka tapi yang diperolehnya secara

\footnotetext{
${ }^{8}$ Andi Hamzah, (1996). Hukum Acara Pidana Indonesia, Sapta Artha Jaya, Jakarta, hlm. 151-152.

${ }^{9}$ M. Yahya Harahap, (2000). Pembahasan Permasalahan dan Penerapan KUHAP Penyidikan dan

Penuntutan, Jakarta : Sinar Grafika, hlm. 261.

${ }^{10}$ Ibid.
} 
melawan hukum atau tanpa izin yang sah menurut perundang-undangan. ${ }^{11}$ Penyitaan barang bukti dalam tahap penyidikan merupakan salah satu hal yang sangat penting jika barang bukti yang dipakai untuk pembuktian tepat, barang bukti tersebut dapat memperkuat kedudukan alat bukti lainnya. Selain itu, barang bukti juga dapat menguatkan keyakinan hakim dalam membuat suatu putusan.

Barang bukti tidak termasuk alat bukti sebagaimana dimaksud dalam Pasal 184 KUHAP. ${ }^{12}$ Barang bukti dalam teori hukum pembuktian disebut sebagai real evidence atau physical evidence. Barang bukti merupakan bukti yang cukup signifikan dalam persidangan perkara pidana. ${ }^{13}$ Barang bukti sebagai real evidence atau physical evidence adalah circumtantial evidence atau bukti tidak langsung yang harus diperkuat oleh kesaksian atau sebaliknya kesaksian diperkuat bukti-bukti lainnya. Dalam konsteks hukum pembuktian dikenal dengan istilah corraborating evidence yang secara harfiah berarti bukti yang diperkuat oleh kesaksian sebelum dipertimbangkan hakim. ${ }^{14}$

Salah satu yang memperkuat physical evidence atau real evidence sebagai bukti adalah ahli untuk mejelaskan physical evidence atau real evidence tersebut dalam rangka membuat terang suatu peristiwa hukum. Physical evidence adalah petunjuk untuk dijajaki lebih lanjut dalam rangka mencari kebenaran suatu fakta yang biasanya disebut dengan istilah trace evidence. ${ }^{15}$

Salah satu ilmu yang berkaitan denga penguaraian physical evidence atau real evidence adalah ilmu forensik. Secara sederhana, ilmu forensik merupakan ilmu pembuktian secara ilmiah terhadap bukti-bukti yang ditemukan ditempat kejadian perkara sesuai dengan disiplin ilmu masingmasing. Barang bukti yang ditemukan kemudian dianalisis dalam rangka mengambil informasi untuk memecahkan masalah yang berkaitan dengan perkara pidana yang ditangani. Intinya, ilmuwan forensik bekerjasama dengan aparat penegak hukum, yang kemudian menghasilkan laporan tertulis sebagai documentary evidence maupun melalui penyampaian langsung di persidangan sehingga hakim dapat membuat putsan berdasarkan informasi yang mendalam atas suatu barang bukti. Dalam ilmu forensik dikenal forensic medicine atau ilmu kedokteran forensik (kesehatan medis), fisika forensik (ilmu fisika), forensic chemistry (ilmu kimia), balistik metallugy forensik (senjata api), dokument forensic (pemalsuan dokumen), uang forensik (uang palsu), fotografi forensik (pemotretan), serta daktilokopi forensik (sidik jari). ${ }^{16}$

Keempat, penyitaan dilakukan untuk kepentingan pembuktian dalam penyidikan, penuntutan, dan peradilan. Barang bukti yang diperoleh dari penyitaan merupakan sumber bukti namun kekuatan pembuktiannya berbeda dengan alat bukti. Barang bukti sekedar dapat digunakan sebagai salah satu bahan membentuk alat bukti petunjuk dan dapat digunakan untuk memperkuat pembentukan keyakinan hakim.17 Ian Dennis mendefenisikan barang bukti merupakan kata yang digunakan untuk mengacu kepada objek fisik yang

\footnotetext{
11 Ibid.

${ }^{12}$ Lihat Pasal 184 KUHAP menyebutkan alat bukti yang sah terdiri dari 1) keterangan saksi; 2) surat; 3)

keterangan ahli; 4) petunjuk; 5) keterangan terdakwa.

${ }^{13}$ Joshua Dressler (Edt), (2002). Encylopedia of Crime \& Justice, $2^{\text {nd }}$ Edition, Volume 2, Delinquent \&

Criminal Subcultures-Juvenille Justice Institutions, Gale Group Thomson Learning, New York, hlm. 1698.

14 Ibid., hlm. 1697.

${ }^{15}$ Colin Evans, (2010). Criminal Justice : Evidence, Chelsea House Publishers, New York, hlm. 28.

${ }^{16}$ Abdussalam \& Adri Desasfuryanto, (2019). Buku Pintar Forensik (Pembuktian Ilmiah), PTIK, Jakarta, hlm.

5-6.

17 Colin Evans, Op.Cit., hlm. 31-32.
} 
dihasilkan dalam pemeriksaan di persidangan. Barang bukti berupa objek materiil ini tidak bernilai jika tidak diidentifikasi oleh saksi dan terdakwa. Apabila telah diidentifikasi, barulah bernilai untuk memperkuat keyakinan hakim yang timbul dari alat bukti yang ada. ${ }^{18}$ Jadi, barang bukti sebagai physical evidence atau real evidence tidak berdiri sendiri, melainkan harus didukung oleh keterangan-keterangan, baik saksi, ahli, maupun terdakwa untuk memperkuat pembuktian mengenai kebenaran peristiwa tindak pidana yang terjadi. Singkatnya, untuk kepentingan penyidikan, barang bukti yang disita oleh penyidik digunakan untuk menyakinkan jaksa penuntut umum bahwa benar hasil penyidikan oleh penyidik telah lengkap. Bagi penuntut umum untuk meyakinkan hakim bahwa benar terdakwa telah melakukan tindak pidana yang didakwakan. Bagi hakim yakni untuk memperoleh keyakinan bahwa benar terdakwa telah melakukan tindak pidana sebagaimana yang didakwakan penuntut umum.

Penyitaan terhadap barang bukti sesuai dengan ketentuan Pasal 38 ayat (1) KUHAP hanya dapat dilakukan oleh penyidik. Norma tersebut mempertegas bahwa hanya penyidiklah yang dapat melakukan penyitaan terhadap barang bukti sebagai physical evidence atau real evidence. Penyitaan pun dinegasikan sebagai kegiatan penyidikan yang hanya dapat dilakukan oleh penyidik. Namun, terlepas dari penegasan norma tersebut, realitas yang terjadi adalah pada tingkat pemeriksaan di persidangan terungkap adanya barang bukti yang belum sempat disita oleh penyidik namun memiliki kaitan yang erat dengan peristiwa tindak pidana yang akan dibuktikan penuntut umum. Namun, apabila berangkat dari konsideran Pasal 38 KUHAP, maka jelas penyitaan hanya dapat dilakukan oleh penyidik pada tingkat penyidikan dan tidak dapat dilakukan oleh penuntut umum sebagai manifestasi dari penerapan asas diferensiasi fungsional antara penyidik dan penuntut umum.

\section{Penyitaan Barang Bukti Pada Tingkat Pemeriksaan Persidangan}

Berangkat dari asumsi dasar bahwa hukum untuk manusia bukan manusia untuk hukum, maka kehadiran hukum bukan untuk dirinya sendiri, melainkan untuk sesuatu yang lebih luas dan besar. Itulah sebabnya ketika terjadi permasalahan di dalam hukum, hukumlah yang haris ditinjau dan diperbaiki, bukan manusia yang dipaksa-paksa masuk ke dalam skema hukum. Hukum hanya menjadi sarana untuk menjamin dan menjaga kebutuhan manusia. Hukum tidak lagi dipandang sebagai suatu dokumen yang absolut dan ada secara otonom, sehingga dalam penegakan hukum, penegak hukum tidak boleh terjebak pada kooptasi rules atas hati-nurani yang menyuarakan kebenaran. ${ }^{19}$ Tegasnya, apabila terjadi pertentangan antara keadilan dan kepastian hukum, maka keadilanlah yang harus diprioritaskan. Karena hukum pada dasarnya berfungsi melayani kebutuhan keadilan dan masyarakat sebagaimana postulat aequum et bonum est lex legume yang bermakna sesuatu yang adil dan baik, adalah hukum dari segala hukum. ${ }^{20}$

\footnotetext{
${ }^{18}$ Andi Hamzah, (1996). Hukum Acara Pidana Indonesia, Sapta Artha Jaya, Jakarta, hlm. 255.

${ }^{19}$ Yudi Kristiana, (2016). Pemberantasan Tindak Pidana Korupsi : Perspektif Hukum Progresif, Thafa Media, Yogyakarta, hlm. 11.

${ }^{20}$ Nur Agus Santoso, (2014). Dimensi Aksiologis Dari Putusan Kasus “ST" Kajian Putusan Peninjauan Kembali Nomor : 97PK/Pid.Sus/2012, Jurnal Yudisial Vol. 7 No. 3 Desember 2014, hlm. 217-218.
} 
Dari hal tersebut, maka KUHAP sebagai salah satu pranata hukum pun harus menyesuaikan dengan realitas kebutuhan masyarakat. Penegakan hukum tidak bisa lagi menerapkan KUHAP secara kaku yang berujung pada tidak terwujudkan keadilan subtantif. Dalam kaitannya dengan tindakan penyitaan, tidak dapat dipungkiri sewaktu-waktu, ada saja barang bukti yang luput dari penelitian penuntutan umum pada taha pra penuntutan yang kemudian terungkap pada saat pemeriksaan persidangan. Bagaimapun, surat dakwaan yang disusun oleh penuntut umum hanyalah berdasarkan fakta yang terungkat dalam berkas perkara. Diferensiasi fungsional yang dianut dalam KUHAP membuat penuntut umum yang dikenai kewajiban pembuktian dipersidangan tidak pernah melihat realitas fakta penyidikan secara utuh melainkan hanya terbatas pada lembara-lembara berkas perkara hasil penyidikan. Barang bukti yang muncul dalam fakta persidangan dirasa perlu untuk memenuhi minimum pembuktian guna membuktikan kesalahan terdakwa. Namun, apabila tidak dilakukan penyitaan maka barang bukti tersebut tidak memiliki kekuatan pembuktian.

Memperhatikan pengertian penyitaan yang dirumuskan dalam Pasal 1 butir ke-16 KUHAP yang berbunyi "Penyitaan adalah serangkaian tindakan penyidik untuk mengambil alih dan atau menyimpan di bawah penguasaannya benda bergerak atau tidak bergerak, berwujud atau tidak berwujud, untuk kepentingan pembuktian dalam penyidikan, penuntutan, dan peradilan. Dalam norma Pasal 1 butir ke-16 KUHAP tersebut, maka setidaknya dapat diketahui bahwa : 1) penyitaan dilakukan untuk kepentingan pembuktian pada tingkat penyidikan; 2) penyitaan dilakukan untuk kepentingan pembuktian pada tingkat penuntutan; serta 3) penyitaan dilakukan untuk kepentingan pembuktian pada tingkat peradilan atau pemeriksaan di persidangan. Secara sistematis, KUHAP hanya mengatur tata cara penyitaan untuk kepentingan pembuktian pada tingkat penyidikan namun belum mengatur tata cara penyitaan untuk kepentingan pembuktian pada tingkat penuntutan maupun peradilan atau pemeriksaan di persidangan. Namun, dari norma tersebut setidaknya memberi gambaran bahwa penyitaan sebagai upaya paksa dilakukan tidak hanya untuk kepentingan penyidikan, namun juga untuk kepentingan penuntutan dan peradilan.

Meskipun realitasnya belum memiliki pijakan yang tegas dalam KUHAP, dari pengamatan penulis selaku praktisi hukum, pelaksanaan penyitaan pada saat pemeriksaan di persidangan sudah 2 (dua) kali dilakukan oleh penuntut umum yakni dalam Perkara Nomor : 392/Pid.Sus/2017/PN Bks an. Terdakwa Hendra Widjaja, S.E. dan Perkara Nomor : 334/Pid.B/2019/PN.Ckr an. Terdakwa I Fenny Lusianti Alias Fenny Binti Tintin Sumarni dan Terdakwa II Fiorena Rosevelt Suryali Alias Fio Binti Rossy Erna Widiawati yang masingmasing didakwa melakukan tindak pidana pencucian uang. Adapun dasar dari penuntut umum melakukan penyitaan adalah Pasal 23 ayat (1) dan ayat (2) huruf b Peraturan Jaksa Agung Republik Indonesia Nomor : PER036/A/JA/09/2011 Tentang Standar Operasional Prosedur Penanganan Perkara Tindak Pidana Umum (selanjutnya disebut PERJA 36/2011), serta Keputusan Ketua Mahkamah Agung Republik Indonesia Nomor : KMA/032/SK/IV/2006 Tentang Pemberlakuan Buku II Pedoman Pelaksanaan Tugas Dan Administrasi Pengadilan tanggal 4 April 2006 (selanjutnya disebut KMA 32/2006).

Menurut KMA 32/2006 sub bagian penyitaan perkara tindak pidana, menyebutkan bahwa "apabila dalam persidangan hakim memandang perlu 
dilakukan penyitaan atas suatu barang, maka perintah hakim untuk melakukan penyitaan ditujukan kepada penyidik melalui penuntut umum". Ketentuan dalam KMA 32/2006 membuka peluang bagi penuntut umum untuk melakukan penyitaan pada tahap pemeriksaan di persidangan melalui penyidik. Dapat dilihat, rumusan KMA 32/2006 tersebut sama sekali tidak mengeliminir keberlakukan Pasal 38 ayat (1) KUHAP yang menyatakan hanya penyidik yang mempunyai kewenangan untuk melakukan penyitaan. Berbeda dengan rumusan KMA 32/2006, dalam Pasal 23 ayat (1) dan ayat (2) huruf b PERJA $36 / 2011$ mengatur rumusan tersendiri mengenai konsep penyitaan yang tidak hanya pada tingkat pemeriksaan di persidangan melainkan termasuk pada tingkat penuntutan yakni pemeriksaan tambahan sebagaimana dirumuskan dalam Pasal 23 ayat (1) yang menyebutkan "Dalam hal dilakukan pemeriksaan tambahan atau pemeriksaan di persidangan untuk kepentingan penyelesaian perkara, Penuntut Umum dapat melakukan penyitaan". Pasal 23 ayat (2) menyebutkan penyitaan sebagaimana dimaksud ayat (1) dilaksanakan dengan cara sebagai berikut : (a) Terhadap perkara yang belum di limpahkan ke pengadilan, Kepala Kejaksaan Negeri setelah menerima laporan penyitaan melalui Kepala Seksi Tindak Pidana Umum atau Kepala Cabang Kejaksaan Negeri membuat surat permohonan ijin sita/persetujuan sita kepada Ketua Pengadilan Negeri; atau (b) Terhadap perkara yang sudah di Iimpahkan dan di dalam persidangan ditemukan fakta adanya barang/benda yang semestinya disita, Kepala Kejaksaan Negeri setelah menerima laporan penyitaan melalui Kepala Seksi Tindak Pidana Umum atau Kepala Cabang Kejaksaan Negeri membuat surat permohonan ijin sita/persetujuan sita kepada Ketua Pengadilan Negeri cq. Majelis Hakim yang memeriksa perkara. Dalam Pasal 23 ayat (2) huruf a merupakan penyitaan pada tingkat penuntutan yakni pemeriksaan tambahan yang dilakukan penuntut umum setelah mendapatkan persetujuan penyitaan dari Ketua Pengadilan Negeri. Sedangkan, dalam Pasal 23 ayat (2) huruf b merupakan penyitaan pada tahap pemeriksaan persidangan yang dapat dilakukan penuntut umum setelah mendapat persetujuan penyitaan dari Ketua Pengadilan Negeri. Selain itu, dalam Pasal 23 ayat (3) masih memungkinan dalam hal persidangan sudah dinyatakan ditutup, Penuntut Umum dapat meminta Ketua Majelis Hakim pemeriksa perkara untuk membuka sidang kembali dengan alasan akan mengajukan surat ijin penyitaan sebagaimana dimaksud ayat (1) PERJA 36/2011. Dalam Pasal 23 ayat (4) dan (5) menyebutkan setelah menerima penetapan penyitaan dari Ketua Pengadilan Negeri pada tingkat pemeriksaan tambahan atau penetapan Ketua Majelis Hakim pada tingkat pemeriksaan di persidangan, maka Penuntut Umum melakukan penyitaan berdasarkan Surat Perintah dari Kepala Kejaksaan Negeri yang dalam pelaksanaannya harus disertai dengan berita acara penyitaan. Hal yang menarik dalam KMA 32/2006 dan Pasal 23 ayat (1) dan ayat (2) huruf b PERJA 36/2011, apakah kemudian diperbolehkan melakukan penyitaan terlebih dahulu tanpa menunggu Penetapan Ketua Pengadilan Negeri maupun Penetapan Majelis Hakim dikarenakan keadaan yang sangat perlu dan mendesak, sesuai pasal 34 ayat (2) jo. pasal 38 ayat (2) jo pasal 7 (1) butir d KUHAP. Menurut hemat penulis, oleh karena berdasarkan Pasal 1 butir ke-16 KUHAP yang menyatakan penyitaan dilakukan untuk kepentingan penuntutan dan peradilan atau pemeriksaan di persidangan, maka segala keadaan yang diatur dalam tata cara penyitaan pada tingkat penyidikan secara mutatis mutandis juga berlaku bagi penuntut umum ketika melakukan penyitaan pada tahap penuntutan yakni pemeriksaan tambahan maupun tahap peradilan atau 
pemeriksaan di persidangan. Hal tersebut semata-tama adalah untuk menemukan kebenaran materiil. Penyitaan yang dilakukan penuntut umum tanpa melalui penyidik tersebut pun dapat dilakukan mengingat penuntut umum merupakan jaksa yang berdasarkan Pasal 30 ayat (1) huruf UU RI No. 16 Tahun 2004 Tentang Kejaksaan Republik Indonesia dapat bertindak sebagai penyidik yang mempunyai kewenangan untuk melakukan penyidikan tindak pidana tertentu. Kewenangan penyidikan tindak pidana tertentu dalam hal ini tindak pidana korupsi dan pelanggaran hak asasi manusia yang berat merupakan extra ordinary measure karena objek tindakan pro justisianya adalah extra ordinary crime. Sehingga, secara teknis maupun pengalaman penuntut umum pun mempunyai keterampilan dan pemahaman dalam melakukan penyitaan terhadap barang bukti. Keterampilan dan pemahaman tersebut melegitimasi jaksa penuntut umum dapat melakukan penyitaan secara profesional berdasarkan ketentuan peraturan perundang-undangan.

Meskipun PERJA 36/2011 telah dicabut dengan adanya Peraturan Jaksa Agung Republik Indonesia Nomor 13 Tahun 2019 Tentang Pencabutan Peraturan Jaksa Agung Nomor : PER-036/A/JA/09/2011 Tentang Standar Operasional Prosedur (SOP) Penanganan Perkara Tindak Pidana Umum tanggal 28 Nopember 2019, namun PERJA 36/2011 maupun KMA 32/2006 sebagai peraturan yang secara materi mengatur hal-hal yang umum sehingga mempunyai daya ikat sebagai peraturan perundang-undangan sebagaimana dimaksud dalam Pasal 8 ayat (1) dan (2) UU RI No. 12 Tahun 2011 Tentang Pembentukan Peraturan Perundang-Undangan setidaknya membuka peluang bagi penuntut umum untuk melakukan penyitaan baik pada tingkat penuntutan yakni pemeriksaan tambahan maupun tingkat peradilan atau pemeriksaan di persidangan. Perbedaannya adalah dalam KMA 32/2006, penyitaan ditujukan kepada penyidik melalui penuntut umum, sedangkan dalam Pasal 23 ayat (1) dan ayat (2) huruf b PERJA 36/2011, penyitaan dilakukan langsung oleh penuntut umum. PERJA 36/2011 maupun KMA 32/2006 merupakan peraturan yang lahir ditengah-tengah kebutuhan penegakan hukum yang wajib diresponsif oleh peraturan perundang-undangan diatasnya. Persamaan dan perbedaan antara kedua peraturan tersebut perlu diharmonisasikan sehingga tidak bertentangan dengan KUHAP yang dapat berpotensi menjadikan barang bukti sebagai unlawfull legal evidence, maupun illegally acquired evidence.

Sejalan dengan postulat actori incumbit onus probandi yang bermakna siapa yang mendakwa maka ia wajib membuktikan, penuntut umum memegang beban pembuktian untuk membuktikan dakwaannya. Dari tindakan penyitaanlah kemudian barang bukti sebagai coraborating evidence ${ }^{21}$ memiliki kekuatan pembuktian untuk diitenditifikasi dengan alat bukti lainnya sehingga memperkuat keyakinan hakim atas kebenaran surat dakwaan penuntut umum. Kewenangan penuntut umum untuk melakukan penyitaan pada tingkat pemeriksaan persidangan sangat diperlukan karena penyitaan terhadap barang bukti yang memiliki relevansi dengan pembuktian pada dasarnya dapat memperkuat kedudukan alat bukti lainnya yang secara mutatis mutandis menguatkan keyakinan hakim dalam membuat suatu putusan. Tanpa hal itu, maka penuntut umum tidak dapat membuktikan dakwaannya sehingga terdakwa harus dibebaskan sebagaimana postulat actore non probante reus absolvitur.

\footnotetext{
${ }^{21}$ Makarim, E. (2013). Electronic evidence and electronic signatures in Indonesia: the probative value of digital evidence. Digital Evidence \& Elec. Signature L. Rev., 10, 136. hal, 139
} 


\section{SIMPULAN DAN SARAN}

Pemeriksaan persidangan sebagai bahagian dari sistem peradilan pidana untuk menemukan kebenaran materiil mempunyai peranan yang sangat penting. Pada tingkat inilah pembuktian itu diwujudkan untuk menyakinkan hakim bahwa benar terdakwa bersalah melakukan tindak pidana yang didakwakan kepadanya. Meskipun, tindakan penyitaan hanya dapat dilakukan oleh penyidik pada tingkat penyidikan, namun tidak menghilangkan legitimasi penuntut umum untuk meminta penyitaan terhadap barang bukti pada tingkat pemeriksaan persidangan kepada hakim. Tindakan penyitaan tersebut sama sekali tidak menghilangkan tujuan penyitaan dilakukan adalah untuk kepentingan penuntutan dan peradilan yang bertujuan mewujudkan kebenaran materiil. Diharapkan agar pembentuk undang-undang merevisi KUHAP dengan merespon konsep penyitaan pada tingkat pemeriksaan persidangan sebagaimana yang diatur dalam PERJA 36/2011 maupun KMA $32 / 2006$, sehingga memberi penegasan kepada penuntut umum untuk dapat melakukan penyitaan terhadap barang bukti yang terungkap pada saat pemeriksaan di persidangan.

\section{DAFTAR RUJUKAN}

Abdussalam \& Adri Desasfuryanto. (2019). Buku Pintar Forensik (Pembuktian Ilmiah). PTIK. Jakarta.

Andi Hamzah. (1996). Hukum Acara Pidana Indonesia. Sapta Artha Jaya. Jakarta.

Andi Sofyan dan Asis. (2014). Hukum Acara Pidana Suatu Pengantar. Prenadamedia Group. Jakarta.

Colin Evans. (2010). Criminal Justice : Evidence. Chelsea House Publishers. New York.

Eddy OS. Hiariej. (2012). Teori Dan Hukum Pembuktian. Erlangga. Jakarta.

Eddy OS. Hiariej. (2009). Asas Legalitas dan Penemuan Hukum dalam Hukum Pidana. Erlangga. Jakarta.

Makarim, E. (2013). Electronic evidence and electronic signatures in Indonesia: the probative value of digital evidence. Digital Evidence \& Elec. Signature L. Rev., 10, 136. hal, 139

Joshua Dressler (Edt). (2002). Encylopedia of Crime \& Justice. $2^{\text {nd }}$ Edition. Volume 2. Delinquent \& Criminal Subcultures-Juvenille Justice Institutions. Gale Group Thomson Learning. New York.

M. Yahya Harahap. (2000). Pembahasan Permasalahan dan Penerapan KUHAP Penyidikan dan Penuntutan. Jakarta : Sinar Grafika. 
Nur Agus Santoso, (2014). Dimensi Aksiologis Dari Putusan Kasus “ST” Kajian Putusan Peninjauan Kembali Nomor : 97PK/Pid.Sus/2012. Jurnal Yudisial Vol. 7 No. 3 Desember 2014.

Panauhe, N. (2014). Akibat Hukum Peralihan Tanggung Jawab Penyidik Atas Benda Sitaan. Lex Crimen, 3(1)

Pribadi, I. (2018). Legalitas Alat Bukti Elektronik Dalam Sistem Peradilan Pidana. Lex Renaissance, 3(1), 4.

Satria, H. (2017). Ke Arah Pergeseran Beban Pembuktian. Integritas: Jurnal Antikorupsi Komisi Pemberantasan Korupsi, 3(1).

Sumaidi, S. (2017). Kajian Terhadap Penyitaan Sebagai Pemaksaan Yang Dihalalkan Oleh Hukum. Legalitas: Jurnal Hukum, 8(1), 220-244.

\section{Peraturan}

Keputusan Ketua Mahkamah Agung Republik Indonesia Nomor : KMA/032/SK/IV/2006 Tentang Pemberlakuan Buku II Pedoman Pelaksanaan Tugas Dan Administrasi Pengadilan tanggal 4 April 2006

Peraturan Jaksa Agung Republik Indonesia Nomor : PER- 036/A/JA/09/2011 Tentang Standar Operasional Prosedur Penanganan Perkara Tindak Pidana Umum.

Perkara Nomor : 392/Pid.Sus/2017/PN Bks an. Terdakwa Hendra Widjaja, S.E. dan Perkara Nomor : 334/Pid.B/2019/PN.Ckr an. Terdakwa I Fenny Lusianti Alias Fenny Binti Tintin Sumarni dan Terdakwa II Fiorena Rosevelt Suryali Alias Fio Binti Rossy Erna Widiawati.

Universal Declaration of Human Rights.

Undang-Undang Republik Indonesia Nomor 12 Tahun 2011 Tentang Pembentukan Peraturan Perundang-Undangan.

Undang-Undang Republik Indoensia Nomor 16 Tahun 2004 Tentang Kejaksaan Republik Indonesia.

Yudi Kristiana. (2016). Pemberantasan Tindak Pidana Korupsi : Perspektif Hukum Progresif. Thafa Media. Yogyakarta. 